\title{
Production of dairy cows fed distillers dried grains with solubles in low- and high-forage diets
}

\author{
Sanjeewa D. Ranathunga, ${ }^{1}$ Kenneth F. Kalscheur, ${ }^{2,3}$ Jill L. Anderson, and Kevin J. Herrick ${ }^{4}$ \\ Dairy and Food Science Department, South Dakota State University, Brookings 57007
}

\begin{abstract}
The objective of the study was to investigate the effects of dietary forage and distillers dried grains with solubles (DDGS) concentration on the performance of lactating dairy cows. Twelve Holstein cows were blocked by parity and milk production and assigned to replicated $4 \times 4$ Latin squares with a $2 \times 2$ factorial arrangement of treatments. Diets were formulated to contain low forage [LF; $17 \%$ forage neutral detergent fiber (NDF)] or high forage (HF; $24.5 \%$ forage NDF) and DDGS at 0 or $18 \%$ of diet dry matter. The forage portion of the diet consisted of $80 \%$ corn silage and $20 \%$ alfalfa hay (dry matter basis). A portion of the ground corn and all of the expeller soybean meal and extruded soybeans from 0\% DDGS diets were replaced with DDGS to formulate 18\% DDGS diets. Overall, we found no interactions of forage $\times$ DDGS concentrations for any of the production measures. We observed no effect of diet on dry matter intake. Milk yield was greater when cows were fed LF diets compared with HF diets ( 43.3 vs. $41.5 \mathrm{~kg} / \mathrm{d})$. Milk fat concentration (3.03 vs. $3.38 \%$ ) was lower for cows fed LF diets compared with HF diets, whereas protein concentration (3.11 vs. $2.98 \%$ ) and yield (1.34 vs. $1.24 \mathrm{~kg} / \mathrm{d}$ ) were greater for cows fed LF diets compared with HF diets. Yields of fat, total solids, energy-corrected milk, and feed efficiency were not affected by diets. Cows partitioned equally for milk, maintenance, and body reserves. Replacing starch from ground corn and protein from soybean feeds with DDGS at either 17 or $24.5 \%$ of forage NDF concentration in the diet was cost-effective and did not affect the production performance of lactating dairy cows.
\end{abstract}

Received December 7, 2017.

Accepted August 20, 2018.

${ }^{1}$ Present address: University of Wisconsin-Madison, 1675

Observatory Drive, Madison, WI 53706.

${ }^{2}$ Corresponding author: kenneth.kalscheur@ars.usda.gov

${ }^{3}$ Present address: U.S. Dairy Forage Research Center, USDA-ARS, 1925 Linden Drive, Madison, WI 53706.

${ }^{4}$ Present address: POET Nutrition, 4506 N. Lewis Ave, Sioux Falls, SD 57110.

\section{INTRODUCTION}

Corn distillers dried grains with solubles (DDGS) has become a common feed ingredient in lactating dairy cow diets in the United States over the past decade. Previous research has demonstrated that DDGS can be fed up to $22 \%$ of the diet (on a DM basis) to replace corn and soybean feeds in the lactating dairy cow diets while sustaining (Mjoun et al., 2010; Ranathunga et al., 2010) or increasing (Anderson et al., 2006; Kleinschmit et al., 2006) milk production. It has been recommended that DDGS could be incorporated at $20 \%$ of the diet DM to achieve optimum performance of lactating dairy cows if diets contain at least $50 \%$ forage (Schingoethe et al., 2009). Ranathunga et al. (2010) demonstrated that feeding DDGS up to $21 \%$ of diet DM could be economically advantageous when commodity prices for feeds such as soybean-based protein supplements and grains are expensive. However, Janicek et al. (2008) reported the greatest milk yield when they partially replaced forage, cottonseed, and soybean feeds with $30 \%$ of DDGS.

The major concern with feeding greater amounts of DDGS is the possibility of causing decreased milk fat concentration or milk fat depression (MFD) due to its high fat content. During MFD, milk fat yield can be reduced by $50 \%$ or more with little or no change in yields of lactose or protein (Bauman and Griinari, 2001). In general, no single dietary factor is responsible for MFD, but interactions of dietary factors such as a greater amount of digestible carbohydrates with reduced amounts of fibrous components, inadequate effective fiber, and a greater concentration of UFA could lead to MFD (Lock, 2010). Variable dietary fat concentrations (Kalscheur et al., 2012) with a greater PUFA concentration, predominantly linoleic acid (Schingoethe et al., 2009), are the major risk factors associated with DDGS causing MFD. Other possible risk factors associated with feeding DDGS causing MFD are the inconsistent nutrient composition of DDGS (Belyea et al., 2010), lack of effective fiber from DDGS (Cyriac, 2005), high concentration of highly digestible nonforage fiber from DDGS (Schingoethe et al., 2009), and inclusion of the 
greater amount of fat and fermentable carbohydrates or silage from other sources along with DDGS (RamirezRamirez et al., 2012).

Previous research demonstrated that when corn DDGS is fed with adequate forage NDF, the possibility of preventing MFD exists in lactating dairy cows (Anderson et al., 2006; Kleinschmit et al., 2006; Ranathunga et al., 2010). A meta-analysis conducted by Kalscheur et al. (2012) suggested that milk fat concentration was lower only when cows were fed distillers grains in diets that contained less than $50 \%$ forage. However, we found no prior research investigating the occurrence of MFD when lactating dairy cows were fed DDGS at the suggested optimal inclusion rate around $20 \%$ of diet DM with low- and high-forage diets. Therefore, we designed an experiment to investigate the performance of lactating dairy cows when DDGS is included in diets with different forage NDF concentrations. We hypothesized that including DDGS at $18 \%$ of diet DM with forage NDF concentration $>19 \%$ (DM basis) would not cause MFD and not adversely affect the performance of cows. The primary objective of our study was to investigate the effects of concentrations of forage NDF and DDGS on production performance of lactating dairy cows, especially MFD. A secondary objective was to determine the cost-effectiveness of feeding DDGS with different forage fiber concentrations.

\section{MATERIALS AND METHODS}

\section{Animals, Diets, and Experimental Design}

The study was conducted at the Dairy Research and Training Facility at South Dakota State University. All procedures involving animals were approved by the South Dakota Institutional Animal Care and Use Committee. Twelve Holstein cows 8 multiparous (initial DIM $=107 \pm 17$; initial $\mathrm{BW}=711 \pm 55 \mathrm{~kg}$ ) and 4 primiparous (initial DIM $=92 \pm 18$ DIM; initial $\mathrm{BW}=583 \pm 65 \mathrm{~kg}$ ) $]$ were used in a triplicated $4 \times 4$ Latin square design balanced for carryover effects with 28-d periods. Cows were blocked by parity and milk production for each square. Treatments were randomly assigned to cows within each square. The first 2 wk of each period were used for diet adaptation and the last 2 wk for sampling and data collection. Dietary treatments were arranged as a $2 \times 2$ factorial. Diets were formulated using NRC (2001) to contain low forage (LF; $17 \%$ forage NDF) or high forage (HF; $24.5 \%$ forage NDF) and DDGS at 0 or $18 \%$ (0DG or 18DG) of diet DM (Table 1). Low-forage diets were balanced to contain 17\% forage NDF (41:59 forage-to-concentrate ratio), and $\mathrm{HF}$ diets were balanced to provide $24.5 \%$ forage NDF (60:40 forage-to-concentrate ratio). Forage consisted of $80 \%$ corn silage and $20 \%$ alfalfa hay (DM basis). The DDGS with approximately $30 \% \mathrm{CP}$ and $10 \%$ crude fat $(\mathbf{C F})$ were purchased from a South Dakota ethanol plant (Glacial Lakes Energy LLC, Watertown, SD) as a single shipment to ensure similar composition throughout the experiment. A portion of the ground corn and all of the expeller soybean meal and extruded soybeans from 0DG diets were replaced with DDGS to formulate 18DG diets. A source of rumen-inert fat (Energy Booster 100, Milk Specialties Global, Eden Prairie, MN) was added to all diets to increase dietary $\mathrm{CF}$ concentration and to maintain similar $\mathrm{CF}$ concentrations for all diets. All diets were formulated (NRC, $2001)$ to be similar in CP (18\%), RDP (10.1\%), RUP (7.9\%), and CF concentrations (4.3\%) on a DM basis; diets were also formulated to be isocaloric.

Forages were premixed in a vertical mixer and blended with concentrates in a Calan Data Ranger (American Calan Inc., Northwood, NH) to mix the diets as a TMR. Cows were housed in a freestall barn and fed once daily (0800 h) using Calan Broadbent individual animal feeders (1 cow assigned per feeder). Cows were trained to use the feeding system before the initiation of the experiment. Amounts of feed offered were adjusted to allow for ad libitum intake and 5 to $10 \%$ of refusal. Cows had unlimited access to feed and water, except during milking. Dry matter intake was measured daily for individual cows using data on daily feed offered and refused. The BW and BCS of each cow were recorded at the first $3 \mathrm{~d}$ of the first period and the last $3 \mathrm{~d}$ of each period. Body condition scores were recorded independently by 3 individuals on a scale of 1 to 5 , where 1 represented emaciated and 5 represented obese (Wildman et al., 1982). Mean of the 3 independent BCS was used for the data analysis. Change in $\mathrm{BW}$ and BCS was the difference between the beginning and the end of each period.

\section{Feed Sample Collection and Chemical Analysis}

Samples of corn silage, alfalfa, concentrate mixes, diets, and orts were collected for 3 consecutive days during wk 3 and 4 of each period and stored at $-20^{\circ} \mathrm{C}$ until analyzed. During the experiment, 3 batches of concentrate mixes were prepared for each treatment at the university feed mill. Individual ingredients of DDGS, ground corn, soybean meal (SBM), expeller soybean meal (SoyPlus, West Central Soy, Ralston, IA), extruded soybeans, soyhulls, and a rumen-inert fat from the same batches were sampled each time when concentrates were mixed at the feed mill. Feed samples were made into composites by period except the feed samples collected from the feed mill. All feed samples were dried at $55^{\circ} \mathrm{C}$ in a forced-air oven (style V-23, 
Table 1. Ingredient and nutrient composition of experimental diets ${ }^{1}$

\begin{tabular}{|c|c|c|c|c|}
\hline \multirow[b]{2}{*}{ Item } & \multicolumn{2}{|c|}{ Low forage } & \multicolumn{2}{|c|}{ High forage } \\
\hline & ODG & $18 \mathrm{DG}$ & ODG & $18 \mathrm{DG}$ \\
\hline \multicolumn{5}{|l|}{ Ingredient $(\%$ of $\mathrm{DM})$} \\
\hline Corn silage & 32.8 & 32.8 & 48.0 & 48.0 \\
\hline Alfalfa hay & 8.20 & 8.20 & 12.0 & 12.0 \\
\hline Dried ground corn & 27.8 & 21.5 & 13.6 & 7.3 \\
\hline Distillers dried grains with solubles & 0 & 18.0 & 0 & 18.0 \\
\hline Soybean meal, $44 \% \mathrm{CP}$ & 10.1 & 11.6 & 9.80 & 11.7 \\
\hline Expellers soybean meal $^{2}$ & 8.21 & 0 & 8.70 & 0 \\
\hline Extruded soybeans & 5.00 & 0 & 5.00 & 0 \\
\hline Soybean hulls & 5.00 & 5.00 & 0 & 0 \\
\hline Rumen inert fat ${ }^{3}$ & 0.55 & 0.55 & 0.75 & 0.75 \\
\hline Limestone & 1.20 & 1.31 & 1.05 & 1.20 \\
\hline Salt, white & 0.55 & 0.55 & 0.55 & 0.55 \\
\hline Dicalcium phosphate & 0.15 & 0.05 & 0.10 & 0.05 \\
\hline Dairy-micro premix ${ }^{4}$ & 0.35 & 0.35 & 0.35 & 0.35 \\
\hline Vitamin $\mathrm{E}^{5}$ & 0.05 & 0.10 & 0.05 & 0.10 \\
\hline \multicolumn{5}{|l|}{ Nutrient (\% of DM unless noted) } \\
\hline $\mathrm{DM}$ (\% of diet) & 55.6 & 55.5 & 47.6 & 47.7 \\
\hline $\mathrm{OM}$ & 93.3 & 93.4 & 93.0 & 93.1 \\
\hline $\mathrm{CP}$ & 17.9 & 18.2 & 18.0 & 18.3 \\
\hline $\mathrm{RDP}^{6}$ & 10.1 & 10.1 & 10.2 & 10.3 \\
\hline $\mathrm{RUP}^{6}$ & 7.8 & 8.1 & 7.8 & 8.0 \\
\hline NDF & 25.0 & 28.3 & 29.0 & 32.3 \\
\hline Forage NDF & 16.8 & 16.8 & 24.5 & 24.5 \\
\hline $\mathrm{ADF}$ & 12.8 & 13.7 & 15.1 & 15.9 \\
\hline $\mathrm{NFC}^{7}$ & 46.7 & 42.1 & 42.0 & 37.2 \\
\hline Starch & 28.1 & 24.9 & 23.2 & 18.8 \\
\hline Crude fat & 3.62 & 4.80 & 4.11 & 5.35 \\
\hline Ash & 6.73 & 6.56 & 6.96 & 6.95 \\
\hline $\mathrm{Ca}$ & 0.85 & 0.84 & 0.77 & 0.73 \\
\hline $\mathrm{P}$ & 0.34 & 0.37 & 0.33 & 0.38 \\
\hline $\mathrm{Mg}$ & 0.24 & 0.25 & 0.25 & 0.26 \\
\hline $\mathrm{K}$ & 1.26 & 1.17 & 1.37 & 1.32 \\
\hline $\mathrm{S}$ & 0.17 & 0.19 & 0.18 & 0.19 \\
\hline $\mathrm{NE}_{\mathrm{L}},{ }^{6} \mathrm{Mcal} / \mathrm{kg}$ & 1.61 & 1.61 & 1.61 & 1.62 \\
\hline \multicolumn{5}{|c|}{$\begin{array}{l}{ }^{1} \text { Diets provided varying concentrations of forage and distillers dried grains with solubles; low forage ( } 41 \% \text { of } \\
\text { diet DM) or high forage }(60 \% \text { of diet DM) and distillers dried grains with solubles at } 0 \text { or } 18 \% \text { of diet DM. } 0 \mathrm{DG} \\
=0 \% \text { distillers dried grains with solubles; } 18 \mathrm{DG}=18 \% \text { distillers dried grains with solubles. }\end{array}$} \\
\hline \multicolumn{5}{|c|}{${ }^{2}$ SoyPlus (West Central Soy, Ralston, IA). } \\
\hline \multicolumn{5}{|c|}{${ }^{3}$ Energy Booster 100 (Milk Specialties Global, Eden Prairie, MN). } \\
\hline \multicolumn{5}{|c|}{$\begin{array}{l}{ }^{4} \mathrm{Contained:} 10 \% \mathrm{Mg} ; 2.6 \% \mathrm{Zn} ; 1.7 \mathrm{mg} / \mathrm{kg} \text { of Mn; } 4,640 \mathrm{mg} / \mathrm{kg} \text { of Fe; } 4,712 \mathrm{mg} / \mathrm{kg} \text { of Cu; } 396 \mathrm{mg} / \mathrm{kg} \text { of I; } 119 \\
\mathrm{mg} / \mathrm{kg} \text { of Co; } 140 \mathrm{mg} / \mathrm{kg} \text { of Se; } 2,640,000 \mathrm{IU} / \mathrm{kg} \text { of vitamin A; } 528,000 \mathrm{IU} / \mathrm{kg} \text { of vitamin } \mathrm{D}_{3} ; \text { and 10,560 IU } / \mathrm{kg} \\
\text { of vitamin E (Land O'Lakes, St. Paul, MN). }\end{array}$} \\
\hline \multicolumn{5}{|c|}{${ }^{5}$ Vitamin $\mathrm{E}=44,000 \mathrm{IU} / \mathrm{kg}$} \\
\hline \multicolumn{5}{|c|}{${ }^{6}$ Calculated according to NRC (2001) using analyzed feed values. } \\
\hline${ }^{7} \mathrm{NFC}=100-(\% \mathrm{NDF}+\% \mathrm{CP}+\%$ & ch) & & & \\
\hline
\end{tabular}

Despatch Oven Co., Minneapolis, MN) for $48 \mathrm{~h}$ and then ground through a 2-mm screen using a Wiley mill (model 3; Arthur H. Thomas Co., Philadelphia, PA). Samples were further ground through a $1-\mathrm{mm}$ screen using an ultracentrifuge mill (Brinkman Instruments Co., Westbury, NY). All feed samples were analyzed for $\mathrm{DM}\left(105^{\circ} \mathrm{C}\right.$ for $3 \mathrm{~h}$; Shreve et al., 2006). Ash was determined at $450^{\circ} \mathrm{C}$ for $8 \mathrm{~h}$ (AOAC International, 2006). Crude protein was determined using an automated $\mathrm{N}$ combustion analyzer (Elementar, Analysensysteme GmbH, Hanau, Germany) as described in AOAC International (2006; method 968.06). Concentrations of
NDF (Van Soest et al., 1991) and ADF (Robertson and Van Soest, 1981) were determined sequentially using the Ankom fiber analysis system (Ankom Technology Corp., Macedon, NY). Sodium sulfite and $\alpha$-amylase (Ankom Technology) were added during the NDF extraction. Crude fat was analyzed according to AOAC procedure (method 920.39; AOAC International, 2006) using an Ankom ${ }^{\mathrm{X} 10}$ Extractor (Ankom Technology Corp.) with diethyl ether as the solvent. Starch concentration was determined using an enzyme-based (thermostable $\alpha$-amylase and amyloglucosidase) total starch assay (method 996.11; AOAC International, 
2002; Total Starch Assay Procedure, Megazyme International Ireland Ltd., Wicklow, Ireland). Composites of corn silage, alfalfa hay, DDGS, and TMR were sent to Dairyland Laboratories Inc. (Arcadia, WI) for mineral analysis (Ca, P, K, Mg, and S). Minerals were quantified according to AOAC International (2002) using an inductively coupled plasma spectrometer (Thermo Jarrell Ash, Franklin, MA). The chemical composition of the diets was calculated based on analysis of individual forages (corn silage and alfalfa) and respective concentrate mixes and the dietary proportions of each ingredient in the diet.

\section{Milk Production and Composition}

Cows were milked 3 times per day at 0600, 1400, and $2100 \mathrm{~h}$ and individual milk yields were recorded at each milking. Milk samples were collected from each milking for 2 consecutive days of wk 3 (d 17 and 18) and 4 (d 24 and 25) of each period. All collected milk samples were sent to Heart of America DHIA Laboratory (Manhattan, KS) for milk composition analysis using approved methods of AOAC International (2002). Milk fat, protein, and lactose were analyzed using mid-infrared spectroscopy (Bentley 2000 Infrared Milk Analyzer, Bentley Instruments, Chaska, MN; AOAC International, 2002). The concentration of MUN was analyzed using a chemical methodology based on a modified Berthelot reaction (ChemSpec 150 Analyzer, Bentley Instruments) and SCC was determined using a flow cytometer laser (Somacount 500; Bentley Instruments; AOAC International, 2002). Somatic cell counts were converted to SCS, where SCS $=\log _{10}(\mathrm{SCC})$. Energy-corrected milk was determined using the equation $[(0.327 \times$ milk yield $(\mathrm{kg})]+[12.95 \times$ fat yield $(\mathrm{kg})]+$ $[7.2 \times$ protein yield $(\mathrm{kg})]($ Orth, 1992).

\section{Blood Sampling and Analysis}

Blood was sampled by venipuncture of the coccygeal vessel approximately $3 \mathrm{~h}$ after feeding on d 19 and 20 of each period. Blood was drawn into evacuated tubes (10-mL tube containing $\mathrm{K}_{3}$-EDTA anticoagulant; Becton Dickinson and Co., Rutherford, NJ). The collected blood samples were immediately placed in ice and transported to the laboratory. Samples were centrifuged (500 $\times g$ ) for $20 \mathrm{~min}$ at $4^{\circ} \mathrm{C}$ (Centrifuge CR412, Jouan Inc., Winchester, VA) to separate the plasma. The plasma was stored at $-20^{\circ} \mathrm{C}$ until analysis.

Plasma samples were thawed and composited by period per cow. Plasma concentrations of glucose, BHB, triglycerides (TG), total cholesterol, plasma urea N, free fatty acids, and lactate were determined colorimet- rically using a microplate spectrophotometer (Varian Inc., Walnut Creek, CA). Plasma glucose was analyzed using glucose oxidase (Glucose kit, cat. No. G7521, Pointe Scientific, Canton, MI) based on the Trinder peroxidase phenol aminophenazone reaction (Trinder, 1969). The concentration of BHB in plasma was determined using $\beta$-hydroxybutyrate dehydrogenase and diaphorase (BHB kit, cat. no. H7587-58, Pointe Scientific) following the methods of Williamson et al. (1962). Plasma TG concentration was determined using lipase and glycerophosphate oxidase (TG kit, cat. no. T7532; Pointe Scientific) according to the procedure of Fossati and Lorenzo (1982). Total cholesterol was determined using cholesterol esterase and oxidase (cholesterol kit, cat. no. C7510; Pointe Scientific) following the procedure of Allain et al. (1974). Plasma urea N concentration was determined using diacetyl monoxime (Wybenga et al., 1971; Urea N test, cat. no. 0580, Stanbio Laboratory, Boerne, TX). The concentration of plasma free fatty acids was determined using acyl-CoA synthetase, acyl-CoA oxidase and peroxidase [HR Series free fatty acids-HR (2) Microtiter Procedure; Wako Diagnostics; Richmond, VA] according to the procedure of Johnson and Peters (1993). Plasma lactate concentration was determined using lactate oxidase and peroxidase (Westgard et al., 1972; Lactate reagent set cat. no. L7596, Pointe Scientific).

\section{Energy Balance Calculations}

Energy values were calculated using the following equations. Net energy intake $\left(\mathbf{N E}_{\mathbf{I}}\right)$ was calculated as

$$
\mathrm{NE}_{\mathrm{I}}(\mathrm{Mcal} / \mathrm{d})=\mathrm{NE}_{\mathrm{L}}(\mathrm{Mcal} / \mathrm{kg}) \times \mathrm{DMI}(\mathrm{kg} / \mathrm{d}),
$$

assuming no feed sorting when calculating net energy intake. Net energy for maintenance was calculated as

$$
\mathrm{NE}_{\mathrm{M}}(\mathrm{Mcal} / \mathrm{kg})=\mathrm{BW}^{0.75} \times 0.080(\mathrm{NRC}, 2001),
$$

where $\mathrm{BW}^{0.75}$ is metabolic BW. Net energy for lactation was calculated as

$$
\begin{gathered}
\text { Milk } \mathrm{NE}_{\mathrm{L}}(\mathrm{Mcal} / \mathrm{kg})=\text { milk yield }(\mathrm{kg}) \\
\times[(0.0929 \times \text { fat } \%)+(0.0547 \times \text { protein } \%) \\
+(0.0395 \times \text { lactose } \%)](\mathrm{NRC}, 2001)
\end{gathered}
$$

Energy balance (EB) was calculated as

$$
\mathrm{EB}(\mathrm{Mcal} / \mathrm{d})=\mathrm{NE}_{\mathrm{I}}-\left(\mathrm{NE}_{\mathrm{M}}+\mathrm{NE}_{\mathrm{L}}\right) .
$$

Total reserves energy (TRE) was calculated as 
TRE $($ Mcal $/ \mathrm{kg})=$ proportion empty body fat

$\times 9.4+$ proportion empty body protein

$$
\times 5.55(\mathrm{NRC}, 2001)
$$

where proportion of empty body fat $=0.037683 \times$ BCS(9) (NRC, 2001) and proportion of empty body protein $=0.200886-0.0066762 \times \operatorname{BCS}(9)$, where $\operatorname{BCS}(9)=[($ dairy BCS -1$) \times 2]+1(\mathrm{NRC}, 2001)$. Finally, energy efficiency was calculated as $\mathrm{NE}_{\mathrm{L}} / \mathrm{NE}_{\mathrm{I}}$ $\times 100$.

\section{Economic Analysis of the Diets}

The income over feed cost (IOFC) of the experimental diets was calculated as

$$
\begin{aligned}
& \mathrm{IOFC}=(\$ / \text { cow per day })=\text { all-milk price }(\$ / \mathrm{kg}) \\
& \times \text { daily average milk production }(\mathrm{kg} / \text { cow per day }) \\
& \quad-\text { daily feed cost }(\$ / \text { cow per day }) .
\end{aligned}
$$

Average prices (as fed basis) from January 2006 to December 2015 were used for corn silage $(\$ 49.3 / \mathrm{t})$, alfalfa hay $(\$ 175.6 / \mathrm{t})$, ground corn $(\$ 0.20 / \mathrm{kg}), \mathrm{SBM}(\$ 0.44 /$ $\mathrm{kg})$, expellers soybean meal $(\$ 0.50 / \mathrm{kg})$, extruded beans $(\$ 0.54 / \mathrm{kg})$, DDGS $(\$ 0.23 / \mathrm{kg})$, soyhulls $(\$ 0.19 / \mathrm{kg})$, rumen-inert fat $(\$ 1.69 / \mathrm{kg})$, dicalcium phosphate $(\$ 0.76 /$ $\mathrm{kg})$, dairy micro premix $(\$ 0.77 / \mathrm{kg})$, limestone $(\$ 0.11 /$ $\mathrm{kg})$, salt $(\$ 0.20 / \mathrm{kg})$, and vitamin E $(\$ 1.88 / \mathrm{kg})$. Price of corn silage was calculated as the price of corn grain per bushel $\times 10$. Prices of corn grain and alfalfa hay were obtained from ERS (2016), and price of expeller soybean meal was obtained from Dairy Nutrition Plus Inc., Ames, Iowa. Prices of all other ingredients were obtained from the South Dakota State University Feed Processing Unit. Milk component prices were calculated from South Dakota State University Dairy Research and Training Facility from January 2006 to December 2015. Average prices from January 2006 to December 2015 for milk fat, protein, and other solids were $\$ 3.92$, $\$ 6.46$, and $\$ 0.54 / \mathrm{kg}$, respectively.

\section{Statistical Analysis}

All data were analyzed using the MIXED procedure in SAS version 9.3 (SAS Institute Inc., Cary, NC). Means of DMI and milk yield from the final 2 wk of each period were used for statistical analysis. Means for milk composition were determined from individual samples taken at each milking twice weekly during wk 3 and 4. Plasma metabolites, BW, BW change, BCS, and BCS change for each cow per period were used for statistical analysis.
The design of this experiment was a multiple Latin square (Mead et al., 2003) with a $2 \times 2$ arrangement of treatments. Cows were assigned to squares by parity and milk production; therefore, primiparous cows were assigned to 1 square and multiparous cows were assigned to the remaining 2 squares by production level. Because all 3 squares were conducted simultaneously, the row effect (period) was assumed to be the same for all 3 squares. The 3 squares were combined to form a Latin rectangle (Mead et al., 2003). The data were analyzed using the MIXED procedures of SAS (version 9.2, SAS Institute Inc.).

Data were analyzed with the model

$$
\begin{aligned}
& \mathrm{Y}_{\mathrm{ijklm}}=\mu+\text { forage } \mathrm{NDF}_{\mathrm{i}}+\text { DDGS }_{\mathrm{j}} \\
& +\left(\text { forage } \mathrm{NDF}_{\mathrm{i}} \times \mathrm{DDGS}_{\mathrm{j}}\right)+\mathrm{PAR}_{\mathrm{k}} \\
& +\left(\text { forage } \mathrm{NDF}_{\mathrm{i}} \times \text { parity }_{\mathrm{k}}\right)+\left(\mathrm{DDGS}_{\mathrm{j}} \times \text { parity }_{\mathrm{k}}\right) \\
& +\left(\text { forage } \mathrm{NDF}_{\mathrm{i}} \times \mathrm{DDGS}_{\mathrm{j}} \times \text { parity }_{\mathrm{k}}\right) \\
& +\mathrm{PER}_{\mathrm{l}}+\mathrm{C}_{\mathrm{m}(\mathrm{PARk})}+\varepsilon_{\mathrm{ijklm}},
\end{aligned}
$$

where $Y_{\mathrm{ijklm}}$ is the dependent variable, $\mu$ is the overall mean, forage $\mathrm{NDF}_{\mathrm{i}}$ is the effect of forage NDF concentration $\mathrm{i}(\mathrm{i}=1$ to 2$), \mathrm{DDGS}_{\mathrm{j}}$ is the effect of DDGS concentration $\mathrm{j}$ ( $\mathrm{j}=1$ to 2 ), (forage $\mathrm{NDF}_{\mathrm{i}} \times \mathrm{DDGS}_{\mathrm{j}}$ ) is the effect of the interaction of forage NDF concentration $\mathrm{i}$ and DDGS concentration $\mathrm{j}, \mathrm{PAR}_{\mathrm{k}}$ is the effect of parity $\mathrm{k}(\mathrm{k}=1$ to 2$), \mathrm{PER}_{1}$ is the effect of period $\mathrm{l}$ $(\mathrm{l}=1$ to 4$), \mathrm{C}_{\mathrm{m} \text { (PARk) }}$ is the effect of cow $\mathrm{m}(\mathrm{m}=1$ to 12 ) nested within parity $\mathrm{k}$, and $\varepsilon_{\mathrm{ijklm}}$ is the residual error. The experimental design used cow as experimental unit and cow nested within parity as the random effect. Interactions with parity were not significant and were dropped from the model. Least squares means are reported for each variable. Statistical significance of main effects and their interaction were declared significant at $P \leq 0.05$, and tendencies for main effects were declared at $0.05<P \leq 0.10$. Mean comparisons using the PDIFF test were performed when there were significant interactions between main effects $(P \leq 0.05)$.

\section{RESULTS}

\section{Dietary Treatments}

The ingredient and chemical composition of the diets, concentrate mixes, corn silage, alfalfa hay, DDGS, ground corn, SBM, expellers soybean meal, extruded soybeans, and $\mathrm{SH}$ are presented in Tables 1 and 2. The concentrations of $\mathrm{OM}, \mathrm{CP}$, and $\mathrm{NE}_{\mathrm{L}}$ were similar across diets and averaged $93.2 \%, 18.1 \%$, and $1.61 \mathrm{Mcal} / \mathrm{kg}$, respectively. Forage NDF concentration for HF and LF diets were 24.5 and $16.8 \%$, respectively. Dietary NDF 
Table 2. Concentration of nutrients (\% of DM unless noted) in concentrate mixes, corn silage, alfalfa hay, distillers dried grains with solubles (DDGS), ground corn, soybean meal, expellers soybean meal, extruded soybeans, and soy hulls used in the diets during the lactation study

\begin{tabular}{|c|c|c|c|c|c|c|c|c|c|c|c|c|}
\hline \multirow{2}{*}{ Item } & \multicolumn{4}{|c|}{ Concentrate $\operatorname{mix}^{1}$} & \multirow{2}{*}{$\begin{array}{l}\text { Corn } \\
\text { silage }\end{array}$} & \multirow{2}{*}{$\begin{array}{c}\text { Alfalfa } \\
\text { hay }\end{array}$} & \multirow{2}{*}{ DDGS } & \multirow{2}{*}{$\begin{array}{l}\text { Ground } \\
\text { corn }\end{array}$} & \multirow{2}{*}{$\begin{array}{c}\text { Soybean } \\
\text { meal }\end{array}$} & \multirow{2}{*}{$\begin{array}{c}\text { Expeller } \\
\text { soybean } \\
\text { meal }^{2}\end{array}$} & \multirow{2}{*}{$\begin{array}{l}\text { Extruded } \\
\text { soybeans }\end{array}$} & \multirow{2}{*}{$\begin{array}{l}\text { Soy } \\
\text { hulls }\end{array}$} \\
\hline & \multicolumn{2}{|c|}{ Low forage } & \multicolumn{2}{|c|}{ High forage } & & & & & & & & \\
\hline DM (\%) & 88.0 & 88.0 & 88.6 & 88.7 & 32.4 & 86.9 & 89.0 & 90.0 & 90.9 & 90.8 & 96.0 & 93.0 \\
\hline $\mathrm{CP}$ & 23.6 & 24.0 & 30.3 & 31.0 & 7.68 & 18.2 & 32.5 & 7.80 & 51.6 & 45.2 & 38.3 & 12.8 \\
\hline NDF & 13.9 & 19.6 & 11.1 & 19.3 & 40.8 & 41.4 & 35.3 & 7.76 & 10.3 & 20.5 & 8.94 & 62.8 \\
\hline Crude fat & 3.87 & 5.86 & 5.39 & 8.49 & 3.49 & 2.33 & 13.2 & 3.90 & 1.85 & 6.37 & 20.0 & 2.82 \\
\hline Ash & 7.54 & 7.26 & 9.07 & 9.02 & 4.65 & 9.23 & 6.73 & 0.58 & 7.42 & 6.88 & 5.98 & 5.50 \\
\hline $\mathrm{Ca}$ & 1.14 & 1.11 & 1.26 & 1.15 & 0.23 & 1.32 & 0.03 & - & - & - & - & - \\
\hline $\mathrm{P}$ & 0.42 & 0.48 & 0.50 & 0.61 & 0.23 & 0.21 & 0.74 & - & - & - & - & - \\
\hline $\mathrm{Mg}$ & 0.25 & 0.26 & 0.28 & 0.32 & 0.20 & 0.33 & 0.32 & - & - & - & - & - \\
\hline $\mathrm{K}$ & 1.20 & 1.05 & 1.42 & 1.29 & 1.19 & 1.96 & 1.08 & - & - & - & - & - \\
\hline S & 0.20 & 0.23 & 0.24 & 0.28 & 0.12 & 0.19 & 0.33 & - & - & - & - & - \\
\hline
\end{tabular}

${ }^{1}$ Concentrate mixes of diets that provided varying concentrations of forage and distillers dried grains with solubles; low forage (41\% of diet DM) or high forage (60\% of diet DM) and distillers dried grains with solubles at 0 or $18 \%$ of diet DM. $0 \mathrm{DG}=0 \%$ distillers dried grains with solubles; $18 \mathrm{DG}=18 \%$ distillers dried grains with solubles

${ }^{2}$ SoyPlus (West Central Soy, Ralston, IA).

and ADF concentrations were greater for HF diets by 4.00 and 2.25 percentage units, respectively, compared with LF diets. Dietary NDF and ADF concentrations were also greater for $18 \mathrm{DG}$ diets by 3.30 and 0.85 percentage units, respectively, compared with 0DG diets. The LF $0 \mathrm{DG}$ and 18DG and HF $0 \mathrm{DG}$ and 18DG diets were formulated to contain starch concentrations of 30.1, $25.8,23.0$, and $18.8 \%$ respectively; however, chemical analysis of diets fed to cows showed that starch concentrations were decreased by 1.9 and 0.9 percentage units in LF $0 D G$ and 18DG diets, respectively. Diets were formulated to have a similar CF concentration of $4.30 \%$ across the diets; however, chemical analysis of diets fed to cows showed that CF concentration of LF ODG and 18DG and HF $0 \mathrm{DG}$ and 18DG diets were 3.62, 4.80, 4.11 , and $5.35 \%$, respectively, based on diethyl ether as the solvent.

\section{Nutrient Intakes}

Nutrient intake of cows fed the experimental diets is presented in Table 3. No significant forage NDF $\times$ DDGS interactions were observed for any of the intake of nutrients. The dietary treatments did not affect DMI when expressed in absolute amounts or as a percentage of BW. We also observed no dietary effect on CP intake, as the $\mathrm{CP}$ concentrations and DMI were similar across the diets; average $\mathrm{CP}$ intake was $4.61 \mathrm{~kg} / \mathrm{d}$. Intakes of total NDF, nonforage NDF, and ADF as kilograms per day and as a percentage of $\mathrm{BW}$ were greater for $\mathrm{HF}$ diets compared with LF diets and greater for 18DG diets compared with ODG diets. Cows fed HF diets con- sumed a greater amount of forage NDF compared with the cows fed LF diets $(6.14$ vs. $4.34 \mathrm{~kg} / \mathrm{d} ; P<0.001)$.

\section{Milk Production and Composition}

Average daily milk yield was greater for cows fed LF diets compared with cows fed HF diets (43.3 vs. $41.5 \mathrm{~kg} / \mathrm{d} ; P=0.02$; Table 4$)$. Cows fed HF diets had greater $(P=0.02)$ milk fat concentration $(3.38 \%)$ compared with cows fed LF diets $(3.03 \%)$. Milk protein concentration (3.11 vs. $2.98 \% ; P<0.001)$, milk protein yield (1.34 vs. $1.24 \mathrm{~kg} / \mathrm{d} ; P<0.001)$, and lactose yield (2.17 vs. $2.03 \mathrm{~kg} / \mathrm{d} ; P<0.001)$ were greater for cows fed LF diets compared with HF diets. Forage NDF concentration did not affect TS concentration, fat yield, TS yield, ECM yield, feed efficiency (defined as ECM/ DMI), and SCS. High-forage diets resulted in greater MUN concentration compared with LF diets (13.4 vs. $12.1 \mathrm{mg} / \mathrm{dL}$ ). The inclusion of DDGS did not affect animal performance measures. No significant forage NDF $\times$ DDGS interactions were observed for any of the reported animal performance measures.

\section{Energy Partitioning and Plasma Metabolites}

Data on BW, BCS, and EB of cows fed during the experiment are presented in Table 5. Average initial BW of cows was $658 \mathrm{~kg}$. Final BW of cows fed LF diets tended to be greater than cows fed HF diets $(P=0.08$; 668 vs. $662 \mathrm{~kg}$ ). Final BW of cows fed 0DG diets were greater than cows fed $18 \mathrm{DG}$ diets $(P=0.02 ; 670$ vs. $661 \mathrm{~kg})$. The BCS change was greater for cows fed LF 
RANATHUNGA ET AL.

Table 3. Consumption of nutrients by cows fed experimental diets ${ }^{1}$

\begin{tabular}{|c|c|c|c|c|c|c|c|c|}
\hline \multirow[b]{2}{*}{ Item (DM basis) } & \multicolumn{2}{|c|}{ Low forage } & \multicolumn{2}{|c|}{ High forage } & \multirow[b]{2}{*}{ SEM } & \multicolumn{3}{|c|}{$P$-value ${ }^{2}$} \\
\hline & ODG & $18 \mathrm{DG}$ & ODG & $18 \mathrm{DG}$ & & $\mathrm{F}$ & DG & $\mathrm{F} \times \mathrm{DG}$ \\
\hline \multicolumn{9}{|l|}{$\overline{\mathrm{DM}}$} \\
\hline $\mathrm{kg} / \mathrm{d}$ & 25.6 & 26.1 & 25.1 & 25.1 & 0.56 & 0.12 & 0.67 & 0.58 \\
\hline$\%$ of BW & 3.89 & 3.94 & 3.83 & 3.80 & 0.10 & 0.15 & 0.87 & 0.56 \\
\hline \multicolumn{9}{|l|}{$\mathrm{CP}$} \\
\hline \multirow{2}{*}{\multicolumn{9}{|c|}{$\mathrm{NDF}$}} \\
\hline & & & & & & & & \\
\hline $\mathrm{kg} / \mathrm{d}$ & 6.34 & 7.38 & 7.28 & 8.11 & 0.16 & $<0.001$ & $<0.001$ & 0.48 \\
\hline$\%$ of BW & 0.97 & 1.12 & 1.11 & 1.22 & 0.03 & $<0.001$ & $<0.001$ & 0.43 \\
\hline \multicolumn{9}{|l|}{ Forage NDF } \\
\hline $\mathrm{kg} / \mathrm{d}$ & 4.29 & 4.38 & 6.15 & 6.13 & 0.12 & $<0.001$ & 0.68 & 0.58 \\
\hline$\%$ of BW & 0.65 & 0.66 & 0.94 & 0.93 & 0.02 & $<0.001$ & 0.87 & 0.49 \\
\hline \multicolumn{9}{|l|}{ Nonforage NDF } \\
\hline $\mathrm{kg} / \mathrm{d}$ & 2.11 & 3.02 & 1.11 & 1.92 & 0.06 & $<0.001$ & $<0.001$ & 0.34 \\
\hline$\%$ of BW & 0.32 & 0.45 & 0.17 & 0.29 & 0.01 & $<0.001$ & $<0.001$ & 0.37 \\
\hline \multicolumn{9}{|l|}{$\mathrm{ADF}$} \\
\hline $\mathrm{kg} / \mathrm{d}$ & 3.25 & 3.58 & 3.79 & 3.99 & 0.08 & $<0.001$ & $<0.001$ & 0.34 \\
\hline$\%$ of BW & 0.49 & 0.54 & 0.58 & 0.60 & 0.02 & $<0.001$ & 0.001 & 0.30 \\
\hline \multicolumn{9}{|l|}{ Starch } \\
\hline $\mathrm{kg} / \mathrm{d}$ & 7.24 & 6.51 & 5.82 & 4.68 & 0.14 & $<0.001$ & $<0.001$ & 0.10 \\
\hline \multicolumn{9}{|l|}{ Crude fat } \\
\hline
\end{tabular}

${ }^{1}$ Diets provided varying concentrations of forage and distillers dried grains with solubles; low forage $(41 \%$ of diet DM) or high forage (60\% of diet DM) and distillers dried grains with solubles at 0 or $18 \%$ of diet DM. 0DG $=0 \%$ distillers dried grains with solubles; $18 \mathrm{DG}=18 \%$ distillers dried grains with solubles.

${ }^{2} \mathrm{~F}=$ effect of dietary forage NDF concentration; DG = effect of distillers dried grains with solubles concentration; $\mathrm{F} \times \mathrm{DG}=$ interaction of dietary forage NDF concentration and distillers dried grains with solubles concentration $(P<0.05)$.

Table 4. Performance by mid-lactation cows fed experimental diets ${ }^{1}$

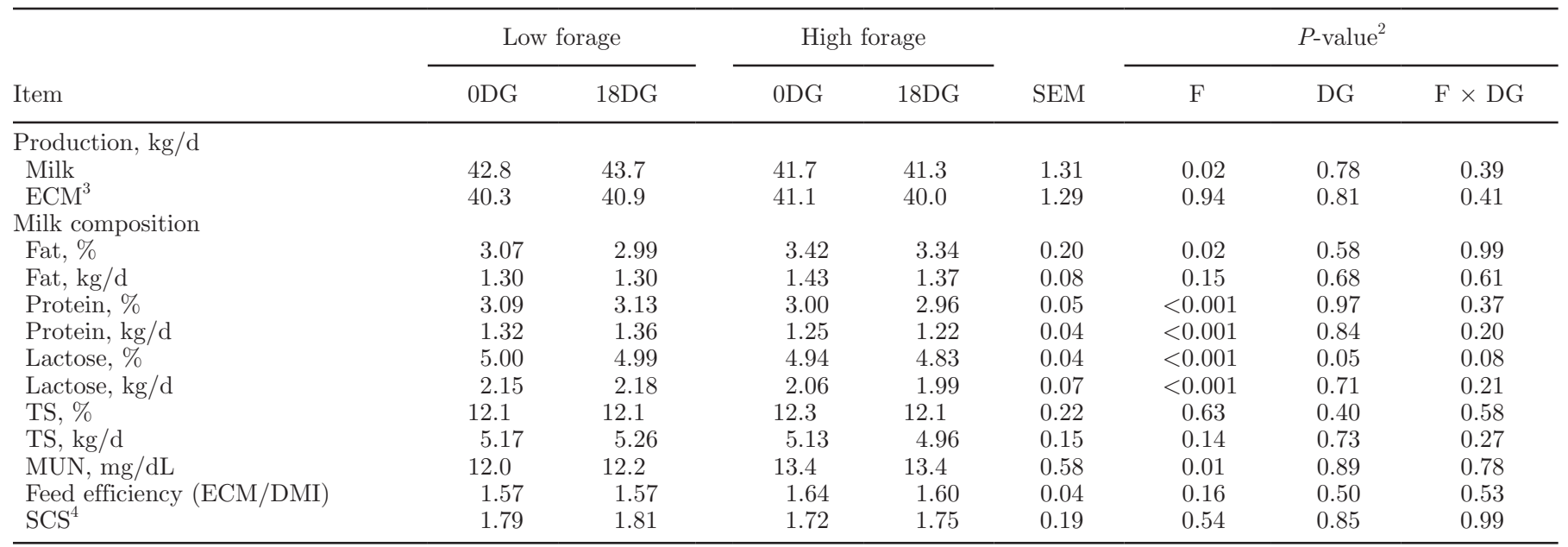

${ }^{1}$ Diets provided varying concentrations of forage and distillers dried grains with solubles; low forage (41\% of diet DM) or high forage (60\% of diet DM) and distillers dried grains with solubles at 0 or $18 \%$ of diet DM. 0 DG $=0 \%$ distillers dried grains with solubles; $18 \mathrm{DG}=18 \%$ distillers dried grains with solubles.

${ }^{2} \mathrm{~F}=$ effect of dietary forage NDF concentration; DG $=$ effect of distillers dried grains with solubles concentration; $\mathrm{F} \times \mathrm{DG}=$ interaction of dietary forage NDF concentration and distillers dried grains with solubles concentration $(P<0.05)$.

${ }^{3} \mathrm{ECM}=[0.327 \times$ milk yield $(\mathrm{kg})]+[12.95 \times$ fat yield $(\mathrm{kg})]+[7.2 \times$ protein yield $(\mathrm{kg})]$.

${ }^{4} \mathrm{SCS}=\log (\mathrm{SCC})$. 
Table 5. Body weight, BCS, and energy balance of mid-lactation cows fed experimental diets ${ }^{1}$

\begin{tabular}{|c|c|c|c|c|c|c|c|c|}
\hline Item & \multicolumn{2}{|c|}{ Low forage } & \multicolumn{2}{|c|}{ High forage } & SEM & \multicolumn{3}{|c|}{$P$-value ${ }^{2}$} \\
\hline Initial BW, $\mathrm{kg}$ & 658 & 661 & 657 & 657 & 16.3 & 0.57 & 0.69 & 0.76 \\
\hline $\mathrm{BW},{ }^{3} \mathrm{~kg}$ & 665 & 662 & 661 & 660 & 16.2 & 0.24 & 0.48 & 0.72 \\
\hline BW change, $\mathrm{kg} / \mathrm{d}$ & 0.58 & 0.04 & 0.36 & -0.08 & 0.15 & 0.14 & 0.14 & 0.15 \\
\hline BCS & 3.02 & 2.99 & 3.00 & 3.01 & 0.04 & 0.95 & 0.66 & 0.32 \\
\hline $\mathrm{NE}_{\mathrm{M}}, \mathrm{Mcal} / \mathrm{d}$ & 10.5 & 10.4 & 10.4 & 10.4 & 0.19 & 0.25 & 0.47 & 0.70 \\
\hline $\mathrm{NE}_{\mathrm{L}}, \mathrm{Mcal} / \mathrm{d}$ & 27.7 & 28.1 & 28.2 & 27.2 & 0.92 & 0.81 & 0.71 & 0.37 \\
\hline $\mathrm{EB},{ }^{5} \mathrm{Mcal} / \mathrm{d}$ & 3.06 & 3.26 & 1.78 & 2.57 & 0.91 & 0.14 & 0.44 & 0.65 \\
\hline $\mathrm{TRE},{ }^{6} \mathrm{Mcal} / \mathrm{kg}$ & 2.71 & 2.70 & 2.70 & 2.71 & 0.03 & 0.95 & 0.66 & 0.32 \\
\hline Energy efficiency $^{7}$ & 67.1 & 67.2 & 69.7 & 67.2 & 1.99 & 0.35 & 0.39 & 0.38 \\
\hline
\end{tabular}

${ }^{1}$ Diets provided varying concentrations of forage and distillers dried grains with solubles; low forage (41\% of diet DM) or high forage (60\% of diet DM) and distillers dried grains with solubles at 0 or $18 \%$ of diet DM. $0 \mathrm{DG}=0 \%$ distillers dried grains with solubles; $18 \mathrm{DG}=18 \%$ distillers dried grains with solubles.

${ }^{2} \mathrm{~F}=$ effect of dietary forage NDF concentration; DG $=$ effect of distillers dried grains with solubles concentration; $\mathrm{F} \times \mathrm{DG}=$ interaction of dietary forage NDF concentration and distillers dried grains with solubles concentration $(P<0.05)$.

${ }^{3} \mathrm{BW}=$ average of the initial and final body weight.

${ }^{4} \mathrm{NE}_{\mathrm{I}}=$ net energy intake.

${ }^{5} \mathrm{~EB}=$ energy balance $=\mathrm{NE}_{\mathrm{I}}-\left(\mathrm{NE}_{\mathrm{M}}+\mathrm{NE}_{\mathrm{L}}\right)$.

${ }^{6} \mathrm{TRE}=$ total reserves energy.

${ }^{7}$ Energy efficiency $=\mathrm{NE}_{\mathrm{L}} / \mathrm{NE}_{\mathrm{I}} \times 100$.

diets compared with cows fed HF diets $(P=0.002)$, whereas the BCS change for cows fed ODG was greater compared with cows fed $18 \mathrm{DG}$ diets $(P=0.05)$. However, we found no effect of dietary treatments on overall BW (average of the initial and final BW), BW change, $\mathrm{BCS}, \mathrm{NE}_{\mathrm{I}}, \mathrm{NE}_{\mathrm{M}}, \mathrm{NE}_{\mathrm{L}}, \mathrm{EB}$, total reserves energy, and energy efficiency.

Plasma concentrations of glucose, BHB, TG, total cholesterol, urea $\mathrm{N}$, free fatty acids, and lactate are presented in Table 6. We noted an interaction of dietary forage NDF and DDGS concentrations for plasma glucose concentration $(P=0.04)$, as the lowest plasma glucose concentration was observed with cows fed the HF 18DG diet compared with other 3 diets (59.7 vs. $65.6 \mathrm{mg} / \mathrm{dL})$. Cows fed HF diets had a greater urea $\mathrm{N}$ concentration $(P<0.001 ; 14.5$ vs. $12.5 \mathrm{mg} / \mathrm{dL})$ compared with cows fed LF diets. Cows fed 18DG diets had a greater plasma total cholesterol concentration compared with cows fed 0 DG $\operatorname{diets}(P=0.01 ; 151$ vs. 132 $\mathrm{mg} / \mathrm{dL})$. The dietary treatments did not affect plasma triglycerides, free fatty acids, and lactate concentrations.

Table 6. Plasma metabolites of mid-lactation cows fed experimental $\operatorname{diets}^{1}$

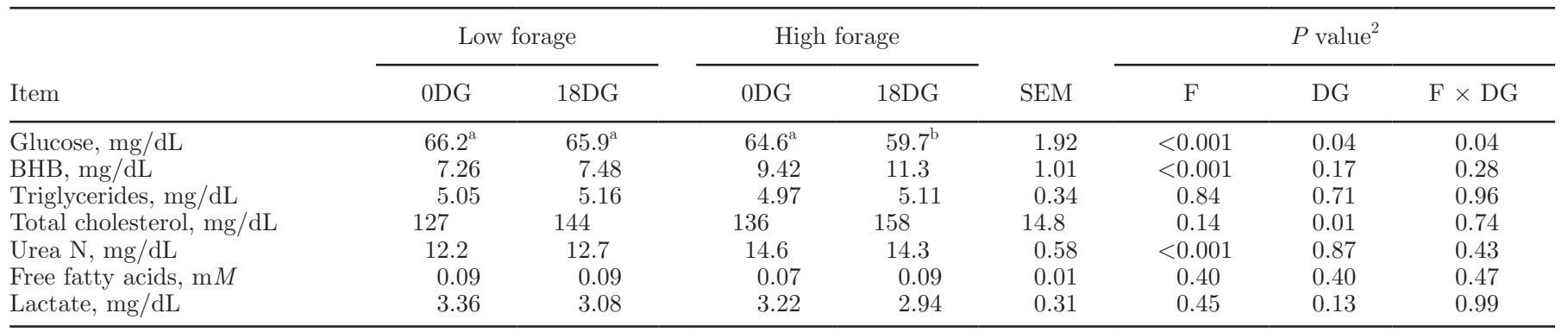

${ }^{\mathrm{a}, \mathrm{b}}$ Treatment means in same row followed by different superscript letters differ significantly $(P<0.05)$.

${ }^{1}$ Diets provided varying concentrations of forage and distillers dried grains with solubles; low forage $(41 \%$ of diet DM) or high forage $(60 \%$ of diet DM) and distillers dried grains with solubles at 0 or $18 \%$ of diet DM. 0DG $=0 \%$ distillers dried grains with solubles; $18 \mathrm{DG}=18 \%$ distillers dried grains with solubles.

${ }^{2} \mathrm{~F}=$ effect of dietary forage NDF concentration; DG $=$ effect of distillers dried grains with solubles concentration; $\mathrm{F} \times \mathrm{DG}=$ interaction of dietary forage NDF concentration and distillers dried grains with solubles concentration $(P<0.05)$. 


\section{Economic Analysis of the Diets}

Average price for class III milk used for all calculations was $\$ 0.352, \$ 0.351, \$ 0.359$, and $\$ 0.353 / \mathrm{kg}$ for $\mathrm{LF}$ 0DG and 18DG and HF 0DG and 18DG diets, respectively. Calculated feed costs (\$/cow per day) were 6.64 , 5.89, 6.46, and 5.63 for LF 0DG and 18DG and HF 0DG and 18DG diets, respectively. Calculated IOFC $\$$ /cow per day) were 8.42, 9.42, 8.52, and 8.92 for LF 0DG and 18DG and HF 0DG and 18DG diets, respectively.

\section{DISCUSSION}

\section{Dietary Treatments}

The NRC (2001) recommends a minimum forage NDF concentration of $19 \%$ to maintain normal rumen function. We aimed to formulate diets with distinctively different high- and low-forage NDF concentrations. Low-forage diets were formulated to have less than $19 \%$ forage NDF, which was below the NRC (2001) recommendation, whereas high-forage diets were formulated to contain more than the NRC (2001) recommendation, which was around $25 \%$ of forage NDF concentration. Dietary inclusion level of DDGS was decided based on the recommended optimum DDGS concentration of $20 \%$ of the diet on DM basis in lactating dairy cow diets (Schingoethe et al., 2009). Our initial attempt was to include $20 \%$ of DDGS on a DM basis; however, it was not possible to formulate all diets with dietary $\mathrm{CP}$ concentration $\leq 18 \%$ on DM basis. Therefore, we restricted the inclusion level of DDGS to $18 \%$ on DM basis. The inclusion of DDGS in 18DG diets was achieved by partially removing ground corn and entirely removing expeller soybean meal and extruded soybeans from $0 D G$ diets. This replacement resulted in lesser starch concentrations and greater NDF and ADF concentrations in 18DG diets compared with 0DG diets. The starch concentration of ground corn used for the diet formulation was greater than the value derived from chemical analysis (77 vs. $73 \%$ DM basis); hence, we observed differences in the starch concentrations in the formulated and actual diets. Similarly, differences observed between formulated and actual values of $\mathrm{CF}$ concentrations for all diets resulted from DDGS having a greater concentration of $\mathrm{CF}(13.2 \%)$ than the value used in the original formulation (10.3\%). Differences in CF concentration of DDGS could be attributed to the solvent used during the analysis. The $\mathrm{CF}$ value we used for our original dietary formulations was derived from a laboratory that used petroleum ether to analyze DDGS. Analysis of CF with diethyl ether may result in greater concentration of $\mathrm{CF}$ compared with that of from petroleum ether (Thiex, 2009). The observed greater $\mathrm{CF}$ concentration for $\mathrm{HF}$ diets could be attributed to the extraction of non-fatty acid compounds by diethyl ether.

\section{Nutrient Intakes}

Previous data indicated that diets containing highforage NDF concentrations may limit DMI based on physical fill of the rumen (Oba and Allen, 2003). However, as observed in our study, diets with highforage NDF concentration may result in similar DMI compared with diets with low-forage NDF concentration (Agle et al., 2010; Aguerre et al., 2011; Neveu et al., 2013). As reviewed by Allen (2000), DMI could be limited by the amount and digestibility of forage and amount of propionate in the rumen rather than the specific ratio of forage to concentrate in the diet. Lowforage diets with greater starch (Voelker et al., 2002; Oba and Allen, 2003) and DDGS (Ramirez-Ramirez et al., 2016) concentrations are known to produce greater molar proportions of propionate in the rumen. Therefore, metabolism of propionate in the liver may have limited the DMI of cows fed LF diets (Allen, 2000).

The effect of feeding corn DDGS up to $20 \%$ of the diet DM on DMI has been variable. Previous experiments (Kleinschmit et al., 2006; Paz et al., 2013; Zanton et al., 2013) demonstrated that inclusion of corn DDGS up to $20 \%$ to replace concentrate ingredients such as ground corn and soybean feeds from control diets did not affect DMI. However, that was not true when Ranathunga et al. (2010) used DDGS and soyhulls to replace ground corn and soybean products, as they observed decreased DMI compared with control diet. Those authors speculated that greater NDF $(>31 \%)$ concentrations along with greater $\mathrm{CF}(>5.1 \%)$ concentrations might have contributed to decreased DMI. As we found no dietary effect on DMI during our study, the variation in intakes of starch, NDF, ADF, and $\mathrm{CF}$ was attributed to the differences in the nutritional composition of respective diets.

\section{Milk Production and Composition}

As we observed, increased milk production with LF diets has been reported consistently (Agle et al., 2010; Aguerre et al., 2011; Manthey et al., 2016). Fermentation of LF diets with greater starch (Agle et al., 2010; Neveu et al., 2013) or DDGS (Ramirez-Ramirez et al., 2016) concentrations are known to produce a greater molar proportion of propionate in the rumen. This effect may have contributed to increased lactose yield via glucose metabolism with LF diets. Differences in lactose yield may have, in part, contributed to the milk yield differences in the LF and HF diets, as lactose 
is the major osmoregulator that controls milk volume (Kuhn et al., 1980).

In agreement with our data, previous studies (Mjoun et al., 2010; Ranathunga et al., 2010) have demonstrated that lactating cows fed diets containing approximately $20 \%$ of the diet DM of corn DDGS produced similar amount of milk yield compared with control diets with no corn DDGS. In our study, the dietary $\mathrm{NE}_{\mathrm{L}}$ content across the diets was similar across the diets, averaging $1.61 \mathrm{Mcal} / \mathrm{kg}$ despite the variable dietary fat concentration across the diets. The ratio of ME supply to requirements according to NRC (2001) was also similar for all diets, averaging $1.07 \pm 0.02$. However, other studies that included DDGS at 20\% DM in the diets observed increased milk production compared with control diets formulated with no corn DDGS (Anderson et al., 2006; Kleinschmit et al., 2006). The reason for discrepancy in milk production responses when feeding DDGS at $20 \%$ DM compared with control diet is not known. Mjoun et al. (2010) indicated that the increase in milk production in the studies cited previously may have resulted from additional fat, which increased in diets containing DDGS. However, the calculated total $\mathrm{NE}_{\mathrm{L}}$ intake was not different between 20\% DDGS and control diets in the cited studies (Anderson et al., 2006; Kleinschmit et al., 2006). Therefore, according to Mjoun et al. (2010), the increase in milk production with DDGS diets compared with control diets may have been caused by an increase in RUP supply with the inclusion of DDGS. The increase in dietary RUP in the 18DG diets versus ODG diets was minimal in our experiment compared with other studies where DDGS was fed at $20 \%$ of the diet (Anderson et al., 2006; Kleinschmit et al., 2006).

According to Bauman and Griinari (2001), dietinduced MFD occurs when lactating dairy cows are fed high-concentrate, low-forage diets or diets supplemented with plant or fish oil. They defined MFD as a reduction of milk fat yield by $50 \%$ or more with no change in milk yield or yield of other milk components. Feeding LF diets with greater starch concentrations is associated with risk factors for causing MFD, such as lesser forage NDF concentration and greater fermentable carbohydrates concentration. Inclusion of DDGS in lactating dairy cow diets in combination with low-forage diets increased risk factors for MFD. These risk factors include increased UFA concentration (Lock, 2010), increased highly digestible NDF concentration (Schingoethe et al., 2009), and decreased effective NDF concentration (Cyriac, 2005). As expected, we observed MFD with cows fed LF diets with or without corn DDGS. We noted a $10 \%$ decrease in milk fat concentration and $7 \%$ numerical decrease in milk fat yield for cows fed the LF diets compared with HF diets. Our observation was in agreement with previously reported MFD associated with LF diets with greater starch (Agle et al., 2010; Neveu et al., 2013) or DDGS concentrations (RamirezRamirez et al., 2016). The meta-analysis conducted by Kalscheur et al. (2012) suggested that milk fat concentration was lower only when cows were fed distillers grains in diets that contained less than $50 \%$ forage. Contrarily, feeding corn DDGS at approximately $20 \%$ of the diet DM with $>19 \%$ forage NDF does not decrease milk fat concentration (Anderson et al., 2006; Kleinschmit et al., 2006; Ranathunga et al., 2010).

Rapid fermentation of highly degradable carbohydrates from starch and DDGS in the rumen may decrease ruminal $\mathrm{pH}$ and fiber digestion by inhibiting fibrolytic bacteria population. Consequently, low-forage diets with greater starch (Agle et al., 2010; Neveu et al., 2013) and DDGS (Ramirez-Ramirez et al., 2016) may produce greater molar proportions of propionate while producing lesser molar proportions of acetate and butyrate in the rumen. This might, in part, be responsible for the observed MFD, as acetate and butyrate are the main precursors of de novo milk FA synthesis (Bauman and Griinari, 2001). Undesirable conditions in the rumen, such as greater concentrations of PUFA in addition to decreased ruminal $\mathrm{pH}$, may also disrupt or overwhelm the ability of rumen microorganism to convert UFA to SFA. Incomplete biohydrogenation may produce intermediates of the CLA, such as trans10,cis-12 C18:2, which could involve in downregulation of the vital lipogenic genes located in the mammary gland involved in milk fat synthesis (Baumgard et al., 2002). Ultimately, this process may decrease the de novo synthesis of fatty acids in the mammary gland, thus leading to MFD. Contrarily, feeding high-forage diets with (Anderson et al., 2006; Kleinschmit et al., 2006; Ranathunga et al., 2010) or without (Agle et al., 2010; Neveu et al., 2013) DDGS to lactating dairy cows may not result in MFD. Greater $\mathrm{pH}$ and improved fiber digestion by fibrolytic bacteria in the rumen of cows fed high-forage diets may result in greater concentrations of the main precursors of de novo milk FA synthesis (i.e., acetate and butyrate). Complete biohydrogenation of UFA in the rumen of cows fed high-forage diets may also inhibit the downregulation of the vital lipogenic genes located in the mammary gland involved in milk fat synthesis.

Increased milk protein concentration and yield associated with LF diets, as observed in our study, are well documented (Aguerre et al., 2011; Neveu et al., 2013). Fermentation of a large proportion of dietary NFC is known to produce a greater molar proportion of propionate, leading to greater plasma insulin concentration (Harmon, 1992). Previous experiments with hyperinsulinemic-euglycemic clamps demonstrated that elevated plasma insulin concentration could improve 
milk protein production (McGuire et al., 1995; Molento et al., 2002). Jenkins and McGuire (2006) also reported that when rapidly degradable carbohydrates are fed with LF diets, a greater proportion of propionate and microbial protein are produced, thus leading to signals for production of more milk and milk protein.

As we observed, previous experiments demonstrated that feeding DDGS at $20 \%$ or less of the diet of midlactation cows usually did not affect milk protein percentage (Anderson et al., 2006; Kleinschmit et al., 2006; Ranathunga et al., 2010). According to a meta-analysis by Kalscheur et al. (2012), milk protein concentration is not affected by the inclusion of distillers grains up to $30 \%$ on a DM basis for lactating dairy cow diets.

\section{Energy Partitioning and Plasma Metabolites}

Data on final BW and BW change may indicate a difference in energy partitioning between cows fed LF and HF diets. However, other parameters on energy partitioning indicated that all cows partitioned energy for milk, maintenance, and body reserves equally. As diets were formulated to be isoenergetic and there was no dietary effect on DMI, all cows appeared to consume equal amounts of energy. Differences observed between LF and HF diets for energy intake in previous experiments were attributed to lesser dietary $\mathrm{NE}_{\mathrm{L}}$ of the diets (Yang et al., 2001), lower DMI associated with HF diets (Weiss and Pinos-Rodríguez, 2009), or both (Neveu et al., 2013). It was apparent that cows spent an equal amount of energy on milk production, as ECM production was not affected by the diets.

Feeding low- or high-forage concentrations may not affect plasma glucose concentration (Manthey et al., 2016). Likewise, feeding DDGS up to $22 \%$ of DM with a greater forage concentration (>49\%; Mjoun et al., 2010; Ranathunga et al., 2010) may not affect plasma glucose concentration of cows compared with cows fed diets without DDGS. Contrarily, the lowest plasma glucose concentration was observed with the cows fed the HF 18DG diet in our study. Reasons for the lowest plasma glucose concentration among cows fed HF 18DG are not known. Greater plasma BHB concentration with cows fed HF diets indicated that HF diets might have resulted in more ruminal acetate and butyrate, precursors of milk fat, as we observed a greater milk fat concentration in HF diets compared with LF diets. Voelker and Allen (2003) reported that plasma BHB was positively correlated with the ruminal pool (molar) of butyrate and milk fat yield. Those authors also observed that plasma BHB tended to be positively correlated with the molar proportion of butyrate in total ruminal VFA, milk fat concentration, and $3.5 \%$ FCM yield. Therefore, Voelker and Allen (2003) presumed that increased availability of BHB and its precursors or products as metabolic fuels might have permitted milk fat synthesis. Increased plasma BHB concentration associated with HF in our study and high milk fat concentration may indicate greater production of butyrate in the rumen of cows fed the HF diets and use of butyrate in milk fat synthesis.

Equal energy status between cows fed LF and HF diets indicated that cows fed HF diets might have obtained a greater amount of energy through digestible forages compared with LF diets. An increased plasma free fatty acids concentration is usually associated with a negative EB (Pullen et al., 1989). Lack of a dietary effect on free fatty acids in the present study was another indication that cows were not subjected to negative EB during the experiment. Elevated plasma cholesterol associated with 18DG diets may result from fatty acids contained in agreement with previous experiments (Mjoun et al., 2010; Ranathunga et al., 2010).

\section{Economic Analysis of the Diets}

The economic analysis of the present study showed a numerical decrease in feed cost when DDGS was included in the diets replacing corn starch, expellers soybean meal, and extruded soybeans. This decrease was attributed to replacing expensive corn starch, expellers soybean meal, and extruded soybeans with lower-cost DDGS. The economic advantage gained from feeding DDGS by replacing starch and soybean products was reflected in the IOFC. According to IOFC analysis, we observed an economic advantage when feeding 18DG diets compared with ODG diets. Our study reaffirms our previous data that demonstrated feeding DDGS up to $20 \%$ is economically beneficial to dairy producers (Ranathunga et al., 2010).

\section{CONCLUSIONS}

Forage NDF concentration affected most of the production parameters of the lactating dairy cows fed during the experiment, but not the addition of DDGS in the lactating dairy cow diets. Data demonstrated that MFD did not result from the addition of DDGS, but from decreasing forage NDF concentration. This experiment demonstrated that DDGS could be fed to lactating dairy cows at a greater inclusion (18\% of diet DM) when diets were formulated to provide adequate effective forage NDF concentration $(24.5 \%$ of diet $\mathrm{DM})$. The replacement of more expensive starch from corn and protein from other feedstuffs with lower-cost DDGS decreased overall diet cost. These findings suggest that lactating cow diets could be formulated to include 18\% DDGS (on a DM basis) with adequate 
forage NDF to prevent adverse conditions such as MFD while maintaining greater milk production.

\section{ACKNOWLEDGMENTS}

The authors express appreciation to Matthew Laubach, Stephen Crego, and Pete Linke, and other personnel at the South Dakota State University Dairy Teaching and Research Facility for the feeding and care of the animals and to Heidi Bruns and Kamal Mjoun of the Dairy and Food Science Department, South Dakota State University, for assistance in sample collection and analysis. This work was supported in part by the South Dakota Agricultural Experiment Station (Brookings) and USDA-ARS Agreement No. 58-5447-7-322, and was a component of NC-1042: Management Systems to Improve the Economic and Environmental Sustainability of Dairy Enterprises.

\section{REFERENCES}

Agle, M., A. N. Hristov, S. Zaman, C. Schneider, P. M. Ndegwa, and V. K. Vaddella. 2010. Effect of dietary concentrate on rumen fermentation, digestibility, and nitrogen losses in dairy cows. J. Dairy Sci. 93:4211-4222. https://doi.org/10.3168/jds.2009-2977.

Aguerre, M. J., M. A. Wattiaux, J. M. Powell, G. A. Broderick, and C. Arndt. 2011. Effect of forage-to-concentrate ratio in dairy cow diets on emission of methane, carbon dioxide, and ammonia, lactation performance, and manure excretion. J. Dairy Sci. 94:30813093. https://doi.org/10.3168/jds.2010-4011.

Allain, C. C., L. S. Poon, C. S. Chan, W. Richmond, and P. C. Fu. 1974. Enzymatic determination of total serum cholesterol. Clin. Chem. 20:470-475.

Allen, M. S. 2000. Effects of diet on short-term regulation of feed intake by lactating dairy cattle. J. Dairy Sci. 83:1598-1624. https:// doi.org/10.3168/jds.S0022-0302(00)75030-2.

Anderson, J. L., D. J. Schingoethe, K. F. Kalscheur, and A. R. Hippen. 2006. Evaluation of dried and wet distillers grains included at two concentrations in the diets of lactating dairy cows. J. Dairy Sci. 89:3133-3142. https://doi.org/10.3168/jds.S0022-0302(06)72587 $-5$.

AOAC International. 2002. Official Methods of Analysis. 17th ed. AOAC Int., Gaithersburg, MD.

AOAC International. 2006. Official Methods of Analysis. 18th ed. AOAC Int., Gaithersburg, MD.

Bauman, D. E., and J. M. Griinari. 2001. Regulation and nutritional manipulation of milk fat: low-fat milk syndrome. Livest. Prod. Sci. 70:15-29. https://doi.org/10.1016/S0301-6226(01)00195-6.

Baumgard, L. H., E. Matitashvili, B. A. Corl, D. A. Dwyer, and D. E. Bauman. 2002. Trans-10,cis-12 conjugated linoleic acid decreases lipogenic rates and expression of genes involved in milk lipid synthesis in dairy cows. J. Dairy Sci. 85:2155-2163. https://doi.org/ 10.3168/jds.S0022-0302(02)74294-X.

Belyea, R. L., K. D. Rausch, T. E. Clevenger, V. Singh, D. B. Johnston, and M. E. Tumbleson. 2010. Sources of variation in composition of DDGS. Anim. Feed Sci. Technol. 159:122-130. https://doi .org/10.1016/j.anifeedsci.2010.06.005

Cyriac, J. 2005. Effect of replacing forage fibre with non-forage fiber in lactating dairy cow diets. MS Thesis. South Dakota State Univ., Brookings.

ERS. 2016. Economic Research Service. United States Department of Agriculture. Accessed August 31, 2017. https://www.ers.usda.gov/ data-products/feed-grains-database/feed-grains-yearbook-tables / \#All\%20tables\%20in\%20one\%20file.
Fossati, P., and P. Lorenzo. 1982. Serum triglycerides determined colorimetrically with an enzyme that produces hydrogen peroxide. Clin. Chem. 28:2077-2080.

Harmon, D. L. 1992. Impact of nutrition on pancreatic exocrine and endocrine secretion in ruminants: A review. J. Anim. Sci. 70:12901301.

Janicek, B. N., P. J. Kononoff, A. M. Gehman, and P. H. Doane. 2008. The effect of feeding dried distillers grains plus solubles on milk production and excretion of urinary purine derivatives. J. Dairy Sci. 91:3544-3553. https://doi.org/10.3168/jds.2007-0777.

Jenkins, T. C., and M. A. McGuire. 2006. Major advances in nutrition: Impact on milk composition. J. Dairy Sci. 89:1302-1310. https:// doi.org/10.3168/jds.S0022-0302(06)72198-1.

Johnson, M. M., and J. P. Peters. 1993. Technical note: An improved method to quantify nonesterified fatty acids in bovine plasma. J. Anim. Sci. 71:753-756.

Kalscheur, K. F., A. D. Garcia, D. J. Schingoethe, F. Diaz Royón, and A. R. Hippen. 2012. Feeding biofuel co-products to dairy cattle. Pages 115-153 in Biofuel Co-Products as Livestock Feed-Opportunities and Challenges. H. P. S. Makkar, ed. FAO. Rome, Italy.

Kleinschmit, D. H., D. J. Schingoethe, K. F. Kalscheur, and A. R. Hippen. 2006. Evaluation of various sources of corn dried distillers grains plus solubles for lactating dairy cattle. J. Dairy Sci. 89:4784-4794. https://doi.org/10.3168/jds.S0022-0302(06)72528 $-0$

Kuhn, N. J., D. T. Carrick, and C. J. Wilde. 1980. Lactose synthesis: The possibilities of regulation. J. Dairy Sci. 63:328-336. https:// doi.org/10.3168/jds.S0022-0302(80)82934-1.

Lock, A. L. 2010. Update on dietary and management effects on milk fat. Pages 15-26 in Proc. Tri-State Dairy Nutr. Conf., Fort Wayne, IN. The Ohio State University Extension, Columbus.

Manthey, A. K., K. F. Kalscheur, A. D. Garcia, and K. Mjoun. 2016. Lactation performance of dairy cows fed yeast-derived microbial protein in low- and high-forage diets. J. Dairy Sci. 99:2775-2787. https://doi.org/10.3168/jds.2015-10014.

McGuire, M. A., J. M. Griinari, D. A. Dwyer, and D. E. Bauman. 1995. Role of insulin in the regulation of mammary synthesis of fat and protein. J. Dairy Sci. 78:816-824. https://doi.org/10.3168/jds .S0022-0302(95)76693-0.

Mead, R., R. N. Curnow, and A. M. Hasted. 2003. Multiple Latin square designs. Pages 81-84 in Statistical Methods in Agriculture and Experimental Biology. 3rd ed. Chapman and Hall/CRC, Boca Raton, FL.

Mjoun, K., K. F. Kalscheur, A. R. Hippen, and D. J. Schingoethe. 2010. Performance and amino acid utilization of early lactating cows fed regular or reduced-fat dried distillers grains with solubles. J. Dairy Sci. 93:3176-3191. https://doi.org/10.3168/jds.2009-2974.

Molento, C. F. M., E. Block, R. I. Cue, and D. Petitclerc. 2002. Effects of insulin, recombinant bovine somatotropin, and their interaction on insulin-like growth factor-I secretion and milk protein production in dairy cows. J. Dairy Sci. 85:738-747. https://doi.org/10 .3168/jds.S0022-0302(02)74131-3.

NRC. 2001. Nutrient Requirements of Dairy Cattle. 7th rev. ed. Natl. Acad. Sci., Washington, DC.

Neveu, C., B. Baurhoo, and A. Mustafa. 2013. Effect of feeding extruded flaxseed with different forage:concentrate ratios on the performance of dairy cows. J. Dairy Sci. 96:3886-3894. https://doi .org/10.3168/jds.2012-6189.

Oba, M., and M. S. Allen. 2003. Effects of corn grain conservation method on feeding behavior and productivity of lactating dairy cows at two dietary starch concentrations. J. Dairy Sci. 86:174183. https://doi.org/10.3168/jds.S0022-0302(03)73598-X.

Orth, R. 1992. Sample day And Lactation Report. DHIA 200 Fact Sheet A-2. Mid-states DRPC, Ames, IA.

Paz, H. A., M. J. de Veth, R. S. Ordway, and P. J. Kononoff. 2013. Evaluation of rumen-protected lysine supplementation to lactating dairy cows consuming increasing amounts of distillers dried grains with solubles. J. Dairy Sci. 96:7210-7222. https://doi.org/ 10.3168/jds.2013-6906.

Pullen, D. L., D. L. Palmquist, and R. S. Emery. 1989. Effect on days of lactation and methionine hydroxy analog on incorporation of 
plasma fatty acids into plasma triglycerides. J. Dairy Sci. 72:49 58. https://doi.org/10.3168/jds.S0022-0302(89)79079-2.

Ramirez-Ramirez, H. A., E. Castillo Lopez, C. J. R. Jenkins, N. D. Aluthe, C. Anderson, S. C. Fernando, K. J. Harvatine, and P. J. Kononoff. 2016. Reduced-fat dried distillers grains with solubles reduces the risk for milk fat depression and supports milk production and ruminal fermentation in dairy cows. J. Dairy Sci. 99:1912-1928. https://doi.org/10.3168/jds.2015-9712.

Ramirez-Ramirez, H. A., K. Nestor, L. O. Tedeschi, T. R. Callaway, S. E. Dowd, S. C. Fernando, and P. J. Kononoff. 2012. The effect of brown midrib corn silage and dried distillers' grains with solubles on milk production, nitrogen utilization and microbial community structure in dairy cows. Can. J. Anim. Sci. 92:365-380. https://doi .org/10.4141/cjas2011-133.

Ranathunga, S. D., K. F. Kalscheur, A. R. Hippen, and D. J. Schingoethe. 2010. Replacement of starch from corn with non-forage fiber from distillers grains and soyhulls in diets of lactating dairy cows. J. Dairy Sci. 93:1086-1097. https://doi.org/10.3168/jds.2009 $-2332$

Robertson, J. B., and P. J. Van Soest. 1981. The detergent system of analysis and its application to human foods. Pages 123-158 in The Analysis of Dietary Fiber in Food. W.P.T. James and O. Theander, eds., Marcel Dekker Inc. New York, NY.

Schingoethe, D. J., K. F. Kalscheur, A. R. Hippen, and A. D. Garcia. 2009. Invited review: The use of distillers products in dairy cattle diets. J. Dairy Sci. 92:5802-5813. https://doi.org/10.3168/ jds.2009-2549.

Shreve, B., N. Thiex, and M. Wolf. 2006. NFTA Method 2.1.4 - Dry Matter by Oven Drying for 3 Hours at $105^{\circ} \mathrm{C}$. NFTA Reference Methods. National Forage Testing Association, Omaha, NE. Accessed February 6, 2014. http://www.foragetesting.org/files/ NFTAReferenceMethodDM-09-18-06.pdf.

Thiex, N. 2009. Evaluation of analytical methods for the determination of moisture, crude protein, crude fat, and crude fiber in distillers dried grains with solubles. J. AOAC Int. 92:61-73.

Trinder, P. 1969. Determination of glucose in blood using glucose oxidase with an alternative oxygen acceptor. Ann. Clin. Biochem. 6:24-27.

Van Soest, P. J., J. B. Robertson, and B. A. Lewis. 1991. Methods for dietary fiber, neutral detergent fiber, and non-starch polysaccha- rides in relation to animal nutrition. J. Dairy Sci. 74:3583-3597. https://doi.org/10.3168/jds.S0022-0302(91)78551-2.

Voelker, J. A., and M. S. Allen. 2003. Pelleted beet pulp substituted for high-moisture corn: 1. Effects on feed intake, chewing behavior, and milk production of lactating dairy cows. J. Dairy Sci. 86:35423552. https://doi.org/10.3168/jds.S0022-0302(03)73959-9.

Voelker, J. A., G. M. Burato, and M. S. Allen. 2002. Effects of pretrial milk yield on responses of feed intake, digestion, and production to dietary forage concentration. J. Dairy Sci. 85:2650-2661.

Weiss, W. P., and J. M. Pinos-Rodríguez. 2009. Production responses of dairy cows when fed supplemental fat in low- and high-forage diets. J. Dairy Sci. 92:6144-6155. https://doi.org/10.3168/jds.2009 -2558 .

Westgard, J. O., B. L. Lahmeyer, and M. L. Birnbaum. 1972. Use of the Du Pont "Automatic Clinical Analyzer" in direct determination of lactic acid in plasma stabilized with sodium fluoride. Clin. Chem. 18:1334-1338.

Wildman, E. E., G. M. Jones, P. E. Wagner, R. L. Boman, H. F. Troutt Jr., and T. N. Lesch. 1982. A dairy cow body condition scoring system and its relationship to standard production characteristics. J. Dairy Sci. 65:495-501. https://doi.org/10.3168/jds .S0022-0302(82)82223-6.

Williamson, D. H., J. Mellanby, and H. A. Krebs. 1962. Enzymatic determination of $\mathrm{D}(-)-\beta$-hydroxybutyrate and acetoacetic acid in blood. Biochem. J. 82:90-96.

Wybenga, D. R., J. D. Giorgio, and V. J. Pileggi. 1971. Manual and automated methods for urea nitrogen measurement in whole serum. Clin. Chem. 17:891-895.

Yang, W. Z., K. A. Beauchemin, and L. M. Rode. 2001. Effects of grain processing, forage to concentrate ratio, and forage particle size on rumen $\mathrm{pH}$ and digestion by dairy cows. J. Dairy Sci. 84:2203-2216. https://doi.org/10.3168/jds.S0022-0302(01)74667-X.

Zanton, G. I., J. Heinrichs, and C. M. Jones. 2013. Short communication: Effects of level of rumen-degradable protein and corn distillers grains in corn silage-based diets on milk production and ruminal fermentation in lactating dairy cows. J. Dairy Sci. 96:4638-4642. https://doi.org/10.3168/jds.2012-6030. 